\title{
ARTICULOS O
}

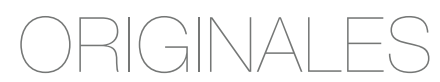

\section{Analysis of the Entry Mode Choice from Both Transaction Costs and Resource Based Theory}

\author{
LUIS ARAYA-CASTILLO* \\ NICOLÁS BARRIENTOS ORADINI** \\ VÍCTOR MANUEL YÁÑEZ-JARA*** \\ ÁNGEL ACEVEDO DUQUE****
}

* PhD en Management Sciences, Doctor en Ciencias de la Gestión y Doctor en Empresa. Investigador. Facultad de Economía y Negocios. Universidad Andrés Bello, Santiago de Chile, Chile. E-mail: I.arayacastillo@uandresbello.edu. ORCID:000o-0o017574-3907. Google Scholar: https://scholar.google.es/citations?hl=es\&user=U2zDNT8AAAAJ.

** PhD en Filosofía en Administración de Empresas. Académico e investigador. Universidad Miguel de Cervantes, Santiago de Chile, Chile. E-mail: nbarrientos@umcervantes.cl. ORCID: 0000-0002-5854-9501. Google Scholar: https://scholar.google. cl/citations?view_op=list_works\&hl=es\&user=xVacvRgAAAA).

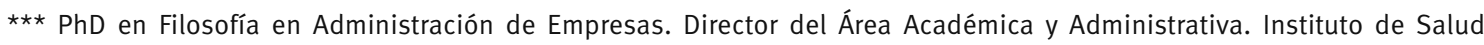
Pública. Universidad Andrés Bello, Santiago de Chile, Chile. Email: victor.yanez@unab.cl. ORCID: 0000-0002-8552-7842. Google Scholar: https://scholar.google.cl/citations?user=v7z-jSUAAAAJ\&hl=es.

$\star \star \star \star$ Postdoctorado en Gerencia Pública y Gobierno, Doctor en Ciencias Gerenciales. Académico e investigador. Facultad de Administracióny Negocios. Universidad Autónoma deChile,Santiago deChile, Chile.E-mail: angel.acevedo@cloud.uautonoma. cl. ORCID: 0000-0002-8774-3282. Google Scholar: https://scholar.google.cl/citations?hl=es\&user=oRTkP8sAAAAJ. 


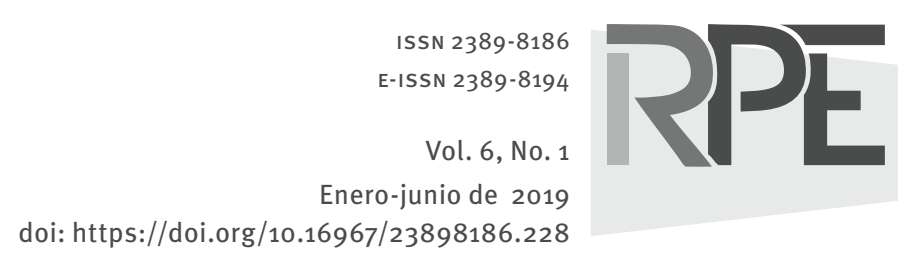

COMO CITAR ESTE ARTÍCULO How to cite this article:

Araya-Castillo, L. et al. (2019). Analysis of the Entry Mode Choice from Both Transaction Costs and Resource Based Theory. Revista Perspectiva Empresarial, 6(1), 7-20

Recibido: 15 de julio de 2018 Aprobado: 22 de octubre de 2018
ABSTRACT The liberalization of markets opened doors for expansion and increased the level of competition in numerous markets. This explains that firms are increasingly diversifying across national borders. This phenomenon is related with the international entrepreneurship, since internationalization is an example of a strategy change that can be defined as an entrepreneurial act. In this context, the scholars in international business have given answers to basically three questions: Why, where, and how do companies internationalize. Since the present research deals with entry modes choice, the focus is clearly on "how." The choice of entry mode constitutes one of the most critical decisions for international strategy success. This research analyzes the entry mode choice from the perspective of both transaction costs and resource based theory, because these perspectives use different assumptions and consider different assumptions. Given this, I propose 4 propositions related with the study of entry mode choice from the transaction costs and resource based theory.

KEY WORDS Internationalization, entry mode choice, transaction costs theory, resource based theory.l

\section{Análisis de la selección del modo de entrada a partir de los costos de transacción y la teoría de los recursos y las capacidades}

RESUMEN La liberación de los mercados abrió las puertas a la expansión e incrementó el nivel de competencia en numerosos mercados. Esto explica que las compañías se estén diversificando cada vez más a través de las fronteras nacionales. Este fenómeno está relacionado con el emprendimiento internacional puesto que la internacionalización es un ejemplo de un cambio de estrategia que puede ser definido como un acto emprendedor. En este contexto, los académicos en el campo de los negocios internacionales han dado respuesta básicamente a tres preguntas: por qué, dónde y cómo se internacionalizan las compañías. Debido a que la presente investigación trata sobre la sección de modos de entrada, el enfoque es claramente sobre el 'cómo'. La selección del modo de entrada constituye una de las decisiones más críticas para el éxito de la estrategia internacional. Esta investigación analiza la selección del modo de entrada tanto desde la perspectiva de los costos de transacción como desde la teoría de los recursos y las capacidades, ya que estas perspectivas usan y consideran diferentes supuestos. Dado lo anterior, hacemos 4 proposiciones relacionadas con el estudio de la selección del modo de entrada a partir de los costos de transacción y la teoría de los recursos y las capacidades.

PALABRAS CLAVE internacionalización, selección del modo de entrada, teoría de los costos de transacción, teoría de los recursos y las capacidades. 


\section{Análise da seleção do modo de entrada a partir dos custos de transações e a teoria dos recursos e as capacidades}

RESUMO A liberação dos mercados abriu as portas à expansão e incrementou o nível de concorrência em muitos mercados. Isto explica que as companhias se estejam diversificando cada vez mais através das fronteiras nacionais. Este fenômeno está relacionado com o empreendimento internacional, já que a internacionalização é um exemplo de uma mudança de estratégia que pode ser definido como um ato empreendedor. Neste contexto, os acadêmicos no campo dos negócios internacionais há dado resposta basicamente a três perguntas: porque, onde, e como se internacionalizam as companhias? Devido a que a presente pesquisa trata sobre a seção de modos de entrada, o enfoque é claramente sobre "como". A seleção do modo de entrada constitui uma das decisões mais críticas para o sucesso da estratégia internacional. Esta pesquisa analisa a seleção do modo de entrada tanto desde la perspectiva dos custos de transação como desde a teoria dos recursos e as capacidades, já que estas perspectivas usam e consideram diferentes supostos. Dado lo anterior, faço 4 proposições relacionadas com o estudo da seleção do modo de entrada a partir dos custos de transação e a teoria dos recursos e as capacidades.

PALAVRAS-CHAVE internacionalização, seleção do modo de entrada, teoria dos custos de transação, teoria dos recursos e as capacidades. 


\section{International Business}

The phenomenon of internationalization of the enterprises is considered one of the principal areas of study of international businesses (Sapienza et al., 2006; Laanti, Gabrielsson and Gabrielsson, 2007), in that entering foreign markets has become an attractive option for enterprise (Bobillo, López-Iturriaga and Tejerina-Gaite, 2012), whether small or large (Lu and Beamish, 2001).

Furthermore, it can be argued that the internationalization of enterprises has become in recent decades a phenomenon that has spread throughout the world, and that has notably facilitated the growth of firms, even in nations that are industrially behind (Binda, 2009). This is because internationalization allows firms to enhance their competitive advantages and performance (Hagemejer and Kolasa, 2011).

This explains that in the last decades, we have observed an increasing internationalization of firms and industries (Johanson and Vahlne, 1990). In this point, Welch and Luostarinen (1988) indicate that internationalization corresponds to the set of activities that facilitate and establish more or less stable ties between companies and international markets, along with a process of growing implication and international projection. In a similar vein, internationalization is understood as the process by which firms both increase their awareness of the direct and indirect influence of international transactions on their future and establish and conduct transactions with other countries (Beamish, 1990).

The international diversification can be understood as the enlargement of the scope of a firm beyond the borders of its country of origin, in not only commercial activities, but also in all activities related to its value chain (Mendoza and Vives, 2008). A more recent definition notes that international diversification is a strategy through which a firm expands the sales of its goods or services across the borders of global regions and countries into different geographic locations or markets (Hitt, Ireland and Hoskisson, 2007).
In this context, multinational enterprise MNE - can be considered the most important force that has accelerated the development of global changes in international economic activity (Dicken, 1992) that can be characterized by the existence of a set of interrelationships between national economies and financial markets (Hitt, Hoskisson and Shimizu, 2006). Many of the world's largest and most successful firms are multinationals (Dastidar, 2009). The MNE consider international expansion as a key strategy to successful competition (Aguilera et al., 2001) and foreign markets as an obligatory reference in their decision making (Mendoza and Vives, 2008).

Considering the last, we can argue that MNE have played a central role in the global economic, social and political changes commonly referred to as globalization (Held and McGrew, 2000). The globalization of economic activity has allowed firms to rapidly shift their activities in the search for new markets (Bobillo, López-Iturriaga and Tejerina-Gaite, 2008). Hill (2001) refers to globalization as a change towards a world economy with a higher degree of integration and interdependence.

Given this, during the past decade the phenomenon of globalization has received considerable attention (Burgel and Murray, 2000). In fact, some scholars have argued that the phenomenon of globalization has induced many companies to internationalize themselves MNE, as a way of being more competitive (Oviatt and McDougall, 1994).

With greater international competition and the rise of emerging market economies, the MNE increasingly face highly uncertain foreign environments in which to do business (Cuypers and Martin, 2010). Thus, multinational firms exist because certain economic conditions and proprietary advantages make it advisable and possible for them to profitably undertake production of a good or service in a foreign location (Guillén and García-Canal, 2009).

Besides, one of the most visible signs of improvement in firm competitiveness in a country is the number and the relevance of its MNE (Camisón, 2007). In that respect, empirical studies conclude that MNE are on average more productive than 
domestic firms (Añón and Manjón, 2009), and respond better to the changes in the competitive environment of global markets (Andersen, 2012). Also, MNE contribute to the economic development of countries in which they operate (Bellak and Chaisse, 2011), fulfilling an important role in the transfer and diffusion of technology and at the same time promoting international trade (Keller, 2000).

This context justifies that in the last 30 years, we have witnessed a growing amount of research about the internationalization of firms (Kim, Hoskisson and Lee, 2015). Evidently, this expanding research reflects an increasing internationalization of firms and industries (Johannes and Vahlne, 1990).

The research in international business has shown an increasing interest in the study of the internationalization of firms (Johanson and Vahlne, 1990), and the scholars have given answers to basically three questions: Why, where, and how do companies internationalize.

Different factors have been proposed in order to explain "why" firms decide to internationalize their operations, such as the liberalization of capital markets, the acceleration of information flows, the higher mobility of people and products, the decline in transportation costs and a relative global regulatory harmonization (Dunning, 2001, 2002; Gatignon and Kimberly, 2004). In this same point, increases in the homogeneity of the markets, improvements in the efficiency of communication and international transport are a more attractive option than before for the firms to internationalize themselves (Bloodgood, Sapienza and Almeida, 1997).

Furthermore, in the literature it is important to analyze "where" the firms decide to internationalize their operations. Flores and Aguilera (2007) argue that some of the key determinants of the foreign entry choices are the firm level characteristics (Horst, 1972; Terpstra and Yu, 1988; Nachum and Zaheer, 2005), the firm relational linkages (Chen and Chen, 1998), as well as country level home (Henisz and Delios, 2001; Harzing and Sorge, 2003) and host country characteristics (Loree and Guisinger, 1995; Dunning, 1998).
The modes of "how" to enter foreign markets can be manifested in the establishment of foreign subsidiaries, in international joint ventures, in licensing agreements, in international advertising campaigns, in international trade, exhibitions and a multitude of other events and actions (Johanson and Vahlne, 1990). This decision is crucial in the internationalization process, because choosing one or another entry mode can have enormous strategic consequences for the firm (Chang and Rosenzweig, 2001).

Finally, we can argue that research area of international business has been studied from diverse perspectives, developing theories that attempt to explain how the process of internationalization is produced in companies. The majority of theories point to the process used by companies to enter into international markets (Räisänen, 2003), or in other words, the input mode.

Thus, the present research has as objective to analyze the entry mode choice from the perspective of both transaction costs and resource based theory. This is how the researchers have found diverse findings where analyze the entry mode choice from both international business and international entrepreneurship approaches, because these perspectives used different assumptions and consider different assumptions.

\section{International Entrepreneurship}

Adaman and Devine (2002) suggest that in the field of economic theory, the entrepreneur concept is used almost exclusively to refer to innovation or activities that balance markets and are executed by individuals or companies in uncertain conditions. This is how it can be argued that, traditionally, the concept of entrepreneurship has been associated with a business-entrepreneur that possesses certain personal characteristics that contribute to a determined form of behavior.

Nevertheless, the concept of entrepreneurship has been carried into the ambit of the organization as a total, and has developed a concept that represents a form of entrepreneurial acting of the organizations, called entrepreneurial orientation. This dimension is formed by three fundamental 
variables: Innovation, risk taking and proactivity (Miller and Friesen, 1983; Covin and Slevin, 1989; Jennings and Young, 1990; Miles and Arnold, 1991; Morris, Avila and Allen, 1993; Caruana, Morris and Vella, 1998).

In addition to the three dimensions previously mentioned, other authors have incorporated two additional dimensions. Knight (2000) suggests that the concept of entrepreneurial orientation reflects the propensity of the firm towards an innovative, proactive and risk-taking behavior, further incorporating the dimensions of autonomy and competitive aggression in order to reach strategic objectives (Dess, Lumpkin and Covin, 1997; Miller and Friesen, 1984).

With this, the concept of entrepreneurship oriented to organizations is analyzed in this research, which is directly related to the decision by firms to operate in international markets. Entrepreneurship helps to facilitate economic growth in several countries which include formerly planned economies (Chow and Fung, 1996).

On the other hand, Welch and Luostarinen (1988) hold that the internationalization of a company is a part of, or a consequence of, the strategy of the firm, and in this sense, internationalization is an example of a strategy change that can be defined as an entrepreneurial act, such as Schumpeter (1944) mentioned.

Given this, it could be argued that the theory of entrepreneurship can be used to analyze the international conduct of a firm (Andersson, 2000). In fact, over the past decade, there has been a growing body of work on international entrepreneurship which has pushed our envelope of knowledge about internationalization of businesses (Rashid, Aziz and Wong, 2010).

Then, it is possible to argue that in recent years the fields of study of entrepreneurship and international business have intersected creating a nascent area of study called international entrepreneurship (Gamboa and Brouthers, 2008). McDougall and Oviatt (2000) have been pioneers in this discipline and define international entrepreneurship as a combination of innovative, proactive and risk-taking conduct that crosses national borders and intends to create value in organizations. Likewise, Dimitratos and Plakoyiannaki
(2003) propose that international entrepreneurship is an ample organizational process included in the organizational culture of the firm, which seeks to generate value by exploiting opportunities in an international market.

Then, we can argue that international entrepreneurship has recognized the emergence of the new international ventures (McDougall and Oviatt, 2000) due to the traditional theories of internationalization are focused principally on large, established and multinational firms (Acs, Dana and Jones, 2003). However, international entrepreneurship is important, not only for small and medium sized companies, but also for large companies (Prokesch, 1997; Zahra and Garvis, 2000).

Since internationalization is a complex, challenging and expensive process, the success of the effort of corporate entrepreneurs can significantly influence the firm's performance. The businesses cannot simply export their domestic business practices to foreign markets and wait to reap the benefits of internationalization. The success in global markets requires companies that are entrepreneurial to decide when, how and where to grow internationally.

Internationalization, then, proportions an important opportunity to study the activities of corporate entrepreneurs and their connection to performance, in new ventures as well as in established companies (Zahra and Garvia, 2000).

\section{Research Proposition}

The choice of entry model constitutes one of the most critical decisions for international strategy success (Pla-Barber, Sánchez and Madhok, 2010; Sanchez-Peinado, Pla-Barber and Hébert, 2007). Root $(1983,1994)$ defines an entry mode as an institutional arrangement that makes possible the entry of a firm's products, technology, human skills, management, or other resources into a foreign country.

Pla-Barber, Sánchez and Madhok (2010) argue that the previous research in international business explains the choice of entry mode from either a sequential or a comparative perspective. 
Both approaches consider all entry modes simultaneously and all factors as being equally relevant at the same time in determining the most suitable entry mode. The broad argument is that modes entailing greater commitment of resources face greater risks, and consequently firms favour modes offering more control to compensate for such risk (Anderson and Gatignon, 1986).

From the sequential perspective, the process of adopting modes of entry into foreign markets is defined as a continuum of increasing degrees of resource commitment, risk exposure, control and profit potential as firms acquire greater knowledge and experience in international business. In contrast, the comparative model analyses multiple entry modes holding one of these as a baseline against which other modes are compared (PlaBarber, Sánchez and Madhok, 2010).

Furthermore, in the current dynamic and competitive environment the entry mode choice is a decision based not only on efficiency and value based considerations, but also on other aspects, such as strategic motives of internationalization or the firm's competitive position in the global environment (Sanchez-Peinado, Pla-Barber and Hébert, 2007).

The internationalization process is manifested in a number of different ways. Johansen and Vahlne (1990) hold that this internationalization process can be seen in the establishment of foreign subsidiaries, in international joint ventures, in licensing agreements, in international advertising campaigns, in international trade, exhibitions and a multitude of other events and actions.

The choice of entry mode in foreign direct investment -FDI-, defined as investment that involves ownership and confers effective management control. Other forms of international expansion, including exporting, licensing and non-equity alliances, do not constitute FDI (Chang and Rosenzweig, 2001).

In this point, $\mathrm{Li}$ and $\mathrm{Li}$ (2010) hold that MNEs can commit to the market by establishing wholly owned subsidiaries -WOSs-, or taking higher equity shares; or they can resort to more flexible strategies by forming joint venture -JV- with local partners, or taking lower equity shares.
Nevertheless, we could argue that the findings about entry mode choice are different depending if the researchers consider either internationalization business or international entrepreneurship approach, since these perspectives consider different assumptions. It is because the bulk of research on foreign operation modes on international business have more or less explicitly assumed that companies internationalize on the basis of market seeking rather than sourcing motives (Welch and Luostarinen, 1988, 1993). And, the literature on international entrepreneurship has conceptualized market entry as an innovative entrepreneurial act (Jones and Coviello, 2005; Simmonds and Smith, 1968) and builds on mainstream entrepreneurship theory in which opportunity is the central focus (Shane and Venkataraman, 2000).

Thus, I assume that the literature about entry mode choice can give us different findings depending of the assumptions considered. Given this, I emphasize the need for studying the entry mode choice from different theories and I propose the following proposition:

Proposition 1: The analysis of entry mode choice could be enriched if is realized from different theories (both transaction costs and resource based theories) rather than from both international business and international entrepreneurship perspectives.

\section{Theories of Entry Mode Choice}

Scholars have made several attempts at developing entry mode choice explanations over the last four decades (Sharma and Erramilli, 2004). Räisänen (2003) hold that the field of research in international business has been divided historically into two very different currents of research: The economic vis ion and the emerging theories.

The term international theory based on economic decisions is an umbrella that incorporates traditional theories and the internationalization models that utilize specific aspects of the economic field. Among these models are those of internationalization and transaction costs, the monopolistic advantage theory and the theory of 
oligopolistic reaction, as well as the resource-based view (Räisänen, 2003). On other hand, among the emerging theories are those of Uppsala model, model of innovation and model of networks.

\section{Transaction Costs Theory}

Li and Li (2010) hold that existing research has extensively examined MNE ownership strategies, using mainly transaction costs theory TCT- as the theoretical tool. This theory emerged from Anderson and Gatignon (1986) application of the transaction costs theory of the firm to entry mode choice analysis of U.S. firms (Sharma and Erramilli, 2004).

Transaction cost research theory typically uses market mediated exchange as the default governance arrangement and identifies market failures stemming from ex post opportunism to justify hierarchical governance structures (Reuer and Ragozzino, 2011). In its application, transaction costs theory is concerned with comparing different institutional arrangements for carrying out economic activity (Williamson, 1985).

Given this, the transaction costs theory provides a decision rule with regard to individual entry decisions (Burgel and Murray, 2000), because its central tenet is to align transactions that differ in their attributes with ownership structures in a way that minimizes transaction costs (Williamson, 1985).

This is how the transaction costs theory sees the internationalization of businesses as a decision based on economic aspects. This theory describes internationalization as a strategic decision that a company makes to select particular markets, input modes of those markets, and to localize commercial activities.

It is because the transaction costs theory assumes that a firm makes the decision to internationalize according to certain aspects, choosing between a set of discreet alternatives based on rational and economic criteria such as cost, risk and capacity for control (Jones and Coviello, 2002).
That is, firms are expected to choose the governance or entry mode that minimizes the costs of carrying out particular transactions. Thus, I formulate the following proposition:

Proposition 2: The transaction costs theory applied to the internationalization of business attempts to explain the selection process of how a business project itself in international markets by comparing the derived costs of the imperfections of the markets which would manifest when the business externalizes the activity as well as the cost of internationalizing the activities.

Li and Li (2010) hold that according transaction costs theory, for investments characterized by high asset specificity, integrated ownership structures, such as WOSs, should be used to enhance MNE strategic and operational control over the assets (Anderson and Gatignon, 1986) and to protect MNE from the risk of knowledge dissemination to their partners (Davidson and McFetridge, 1985; Hill, Hwang and Kim, 1990).

\section{Resource-based Theory}

Sharma and Erramilli (2004) argue that in line with the entry mode literature tradition, the resource based theory -RBT- offers a unique opportunity for the development of entry mode choice explanations from the resource perspective of the firm. This theory explains how the possession of superior administrative orientations, and other capabilities and resources, can serve as important competitive advantages, particularly for small and medium-size businesses that decide to venture in to international markets (Knight, 2001).

Barney (1991) holds that the advantage derives from the firm's control of the resources and capabilities that are valued, rare, imperfectly imitable and not substitutable. These resources and capabilities can be seen as the set of tangible and intangible resources, including administrative skills of a company, routines and their organizational processes, and the information and knowledge that is in control. 
Thus, what resource based has done is that it further relaxed the assumption of competition to make it "dynamic competition" in order to address the currently prevailing competitive conditions (Sharma and Erramilli, 2004). Several leading scholars in international business including, Dunning (1993), Buckley and Casson (1998), Fusari (1996), and Prahalad and Lieberthal (1998) have also recognized that firms are experiencing dynamic competition due to several factors such as the spread of globalization, proliferation of information technologies, and emergence of highly knowledgeable global customers (Sharma and Erramilli, 2004).

Furthermore, the establishment of a sustainable competitive advantage to reap above normal returns on a firm's resources is central to the resource based theory. Since the exploitation of an existing advantage is also central to the entry mode choice literature, the resource based theory seems to be a good candidate for developing reasonably sound explanations of entry mode choices. By virtue of its assumption of dynamic competition and that of resource heterogeneity, the resource based theory can do so by aligning the entry mode decisions with business strategy and by focusing on the notion of competitive advantage (Sharma and Erramilli, 2004). Given this, I formulate the following proposition:

Proposition 3: The resource based theory empowers the explanation of entry mode choices based not only upon the exploitation of existing advantages (as done in the traditional views) but also those modes deployed for the generation of new advantages.

Thus, we can argue that the internationalization has represented an opportunity for those fir$\mathrm{ms}$ that possess some unique capabilities that can be exploited internationally (Lessard, 2003).

\section{Analysis of the Entry Mode Choice from Both Transaction Costs and Resource Based Theories}

Peng (2001) refers to entries into markets (entry mode choice) as a classic strategic problem of international business. Largely influenced by the transaction costs theory, traditional studies treat each particular entrance as a transaction, and the important concern is to trust the measures of the external market.

This is how, considering the discussion realized about the transaction costs theory and resource based theory, I formulate the final proposition:

Proposition 4: In the entry mode choice the resource based theory plays an important role, because it increases the level of analysis from the transaction of the company, suggesting that a particular entry decision cannot be seen as an isolated event, since strategic global posture of the company should also be considered.

It is because the resource based theory attempts to explain internationalization as a strategic decision that depends upon the capabilities and restrictions that arise from the possession of certain resources on the part of the company, such as human capital, directive skills, the industry's own skills and the ability to acquire financial capital (Westhead, Wright and Ucbasaran, 2001).

The same Peng (2001) makes reference in his article to the fact that the resource based theory differs from the transactions costs theory in three important dimensions. First, considering that the transaction costs theory predicts the failure of the input mode in the external market, like the licenses, under the assumption of opportunism, the resource based theory attributes this failure to the heterogeneity of the resources of the companies (Capron, Dussauge and Mitchell, 1998). A second difference is that while the transactions costs theory generally focuses on the entries of just one time based on a play of relatively static conditions, the resource based theory highlights a dynamic process, longitudinal in that multiple entries have a place in the capabilities and learning of the previous experience of the company (Chang, 1995; Chang and Rosenzweig, 2001). Finally, the third difference is related to the specific advantage of the business, considering that the transaction costs theory is focused on its exploitation, the resource based theory in addition to the exploitation incorporates the development (Madhok, 1997). 


\section{Conclusions}

International diversification is a research area that has elicited a great level of interest in recent years (Laanti, Gabrielsson and Gabrielsson, 2007; Cieślik, Kaciak and Welsh, 2010; Kirca et al., 2012). Internationalized firms conceive international expansion as a key strategy for competing successfully (Aguilera et al., 2011) and thus the presence in foreign markets becomes a necessary reference in their strategic decision-making (Mendoza and Vives, 2010).

In the process of internationalization the firms are not only concerned about what foreign markets to enter, and what activities to perform in those markets, but how to enter them (Chang and Rosenzweig, 2001). This situation is relevant, since the mechanisms of the internationalization process have been one of the most widely adopted concepts in international business (Reid and Rosson, 1987), and they affect all the future decisions and operations of the firm in the new market (Pla-Barber, Sánchez and Madhok, 2010).

This decision is crucial in the internationalization process, because choosing one or another entry mode can have enormous strategic consequences for the firm (Chang and Rosenzweig, 2001). This decision has an impact on the possibility of MNE to achieve competitive advantages. The annals of business history report that, for every successful market entry, about four entries fail (Horn, Lovallo and Viguerie, 2005). That is how inexperienced start-ups suffer from some of these disappointments, but so do many sophisticated corporations (Pla-Barber, Sánchez and Madhok, 2010).

Moreover, although previous studies have shed light on various factors underlying entry mode choice, including both macro-level (country risk, cultural distance, market potential) and micro-level (marketing intensity, nature of knowhow, strategy, experience, etc.) variables, the overall understanding of how managers make entry mode selection decisions and what is the underlying heuristic decision as yet remains somewhat unclear (Pla-Barber, Sánchez and Madhok, 2010).

Considering this situation, the international business literature needs to unify the theoretical framework about the entry mode choice. This is due to the introduction of strategic dimensions into the analysis of entry mode choice, which is essential in a world characterized by increasing globalization and the proliferation of cross-border collaborative alliances (Hill, Hwang and Kim, 1990); Dunning, 1993; Sanchez-Peinado, PlaBarber and Hébert, 2007).

In conclusion, the present research analyzes the entry mode choice from the perspective of both transaction costs and resource based theory. Based on this, four theoretical propositions are formulated about the entry modes of the companies that decide to internationalize their operations.

\section{References}

Acs, Z., Dana, L.P. and Jones, M.V. (2003). Toward New Horizons: The Internationalization of Entrepreneurship. Journal of International Entrepreneurship, 1, 5-12.

Adaman, F. and Devine, P. (2002). A Reconsideration of the Theory of Entrepreneurship: A Participatory Approach. Review of Political Economy, 14 (3), 329-355.

Aguilera, J. et al. (2011). La influencia de la diversificación y experiencia internacional en la estrategia medioambiental proactiva de las empresas. Investigaciones Europeas de Dirección y Economía de la Empresa, 17 (1), 75-91.

Andersen, T.J. (2012). Multinational risk and performance outcomes: Effects of knowledge intensity and industry context. International Business Review, 21 (2), 239-252.

Anderson, E. and Gatignon, H. (1986). Modes of Foreign Entry: A Transaction Cost Analysis and Propositions. Journal of International Business Studies, 17 (3), 1-26.

Andersson, S. (2000). The Internationalization of the Firm from an Entrepreneurial Perspective. 
International Studies of Management and Organizations, 30 (1), 63-92.

Añón, H.D. and Manjón, A.M. (2009). Does Internationalization Alter the R\&D, Productivity Relationship? Tarragona, España: Universidad Rovira i Virgili.

Barney, J.B. (1991). Firm Resources and Sustainable Competitive Advantage. Journal of Management, 17 (1), 99-120.

Beamish, P.W. (1990). The internationalization process for smaller Ontario firms: A research agenda. En Rugman, M. (Ed.), Research in Global Strategic Management: International Business Research for the Twenty-First Century; Canada's New Research Agenda (pp. 77-92). Stamford, USA: Jai Pr.

Bellak, C. and Chaisse, J. (2011). Do Bilateral Investment Treaties Promote Foreign Direct Investment? Preliminary Reflections on a New Methodology. Transnational Corporations Review, 3 (4), 3-11.

Binda, V. (2009). La internacionalización de la empresa española en perspectiva histórica. Revista ICE, 849, 9-26.

Bloodgood, J., Sapienza, H. and Almeida, J.G. (1997). The Internationalization of New High-Potential U.S. Ventures: Antecedents and Outcomes. Entrepreneurship Theory \& Practice, 20, 61-76.

Bobillo, A.M., López-Iturriaga, F. and Tejerina-Gaite, F. (2008). International Diversification and Firm Performance: An International Analysis. The Business Review, 9 (2), 84-91.

Bobillo, A.M., López-Iturriaga, F. and Tejerina-Gaite, F. (2012). The Effects of International Diversification on Firm Performance: An Empirical Study across Twelve European Countries. International Journal of Management, 29 (4), 531-542.

Buckley, P.J. and Casson, M.C. (1998). Analyzing foreign market entry strategies: Extending the internalization approach. Journal of International Business Studies, 29 (3), 539-562.

Burgel, O. and Murray, G. (2000). The International Market Entry Choices of Start-Up Companies in High-Technology Industries. Journal of International Marketing, 8 (2), 33-62.

Camisón, C. (2007). Bases organizativas de la internacionalización y la competitividad de la empresa española: dinámica en las dos últimas décadas. Revista ICE, 838, 59-100.
Capron, L., Dussauge, P. and Mitchell, W. (1998). Resource Redeployment following horizontal acquisitions in Europe and North America. Strategic Management Journal, 19, 631-661.

Caruana, A., Morris, M. and Vella, A. (1998). The Effect of Centralization and Formalization on Entrepreneurship in Export Firms. Journal of Small Business Management, 36 (1), 16-29.

Chang, S.J. (1995). International Expansion Strategy of Japanese Firms: Capability Building through Sequential Entry. Academy of Management Journal, 38 (2), 383-407.

Chang, S.J. and Rosenzweig, P.M. (2001). The choice of entry mode in sequential foreign direct investment. Strategic Management Journal, 22, 747-776.

Chen, H. and Chen, T.J. (1998). Network linkages and location choice in foreign direct investment. Journal of International Business Studies, 29 (3), 445-467.

Chow, C. and Fung, M. (1996). Firm dynamics and industrialization in the Chinese economy in transition: Implications for small business policy. Journal of Business Venturing, 11 (6), 489-505.

Cieślik, J., Kaciak, E. and Welsh, D.H.B. (2010). The strategic effect of early internationalization on survival, consistency, and growth of export sales in small/medium sized enterprises. Journal of Small Business Strategy, 21 (4), 39-64.

Covin, J.G. and Slevin, D.P. (1988). The Influence of Organization Structure on the Utility of an Entrepreneurial Top Management Style. Journal of Management Studies, 25 (3), 217-234.

Cuypers, I. and Martin, X. (2010). What makes and what does not make a real option? A study of equity shares in international joint ventures. Journal of International Business Studies, 41, 47-69.

Dastidar, P. (2009). International corporate diversification and performance: Does firm self-selection matter? Journal of International Business Studies, 40 (1), 71-85.

Davidson, W.H. and McFetridge, D.G. (1985). Key characteristics in the choice of international technology transfer mode. Journal of International Business Studies, 16 (2), 5-21. 
Dess, G., Lumpkin G. and Covin, J. (1997). Entrepreneurial Strategy Making and Firm Performance: Test of Contingency and Configurational Models. Strategic Management Journal, 18 (9), 677-695.

Dicken, P. (1992). Global shift: The internationalization of economic activity. London, England: Paul Chapman Pub.

Dimitratos, P. and Plakoyiannaki, E. (2003). Theoretical Foundations of an International Entrepreneurial Culture. Journal of International Entrepreneurship, 1 (2), 187-215.

Dunning, J.H. (1993). The Internationalization of the Production of Services: Some General and Specific Explanations. En Aharoni, Y. (Ed.), Coalitions and Competition: The Globalization of Professional Services (pp. 78-101). London, England: Routledge.

Dunning, J.H. (1998). Location and the multinational enterprise: A neglected factor? Journal of International Business Studies, 29 (1), 45-66.

Dunning, J.H. (2001). The Key Literature on IB Activities: 1960-2000. En Rugman, A.M. and Brewer, T.L. (Ed.), The Oxford Handbook of International Business (pp. 36-68). New York, USA: Oxford University Press.

Dunning, J.H. (2002). Global Capitalism, FDI and competitiveness. Cheltenham, England: Edward Elgar.

Flores, R. and Aguilera, R. (2007). Globalization and location choice: An analysis of US multinational firms in 1980 and 2000. Journal of International Business Studies, 38 (7), 1187-1210.

Fusari, A. (1996). Paths of economic development: modeling factors of endogenous growth. International Journal of Social Economics, 23 (10/11), 164-191.

Gamboa, E.C. and Brouthers, L.E. (2008). How International is Entrepreneurship? Entrepreneurship Theory and Practice, 551-558.

Gatignon, H. and Kimberly, J.R. (2004). Globalization and Its Challenges. En Gatignon, H., Kimberly, J.R. and Gunther, R.E. (Ed.), The INSEAD-Wharton Alliance on Globalizing: Strategies for Building Successful Global Business (pp. 1-22). Cambridge, England: Cambridge University Press.

Guillén, M. and García-Canal, E. (2009). La presencia de la empresa española en el exterior. Madrid, España: ICEX.
Hagemejer, J. and Kolasa, M. (2011). Internationalisation and Economic Performance of Enterprises: Evidence from Polish Firm-Level Data. The World Economy, 34, 74-100.

Harzing, A.W. and Sorge, A.M. (2003). The relative impact of country-of-origin and universal contingencies on internationalization strategies and corporate control in multinational enterprises: World-wide and European perspectives. Organization Studies, 24 (2), 187-214.

Held, D. and McGrew, A. (2000). The Global Transformations Reader: An Introduction to the Globalization Debate. Cambridge, England: Polity Press.

Henisz, W.J. and Delios, A. (2001). Uncertainty, imitation and plant location: Japanese multinational corporations, 1990-1996. Administrative Science Quarterly, 46 (3), 443-475.

Hill, C. (2001). Negocios internacionales: competencia en un mercado global. Ciudad de México, México: McGraw-Hill.

Hill, C.W.L., Hwang, P. and Kim, W.C. (1990). An Eclectic Theory of the Choice of International Entry Mode. Strategic Management Journal, 11 (2), 117-128.

Hitt, M.A., Hoskisson, K. and Shimizu, K. (2006). The importance of resources in the internationalization of professional service firms: The good, the bad and the ugly. Academy of Management Journal, 49 (6), 1137-1157.

Hitt, M.A., Ireland, R.D. and Hoskisson, R.E. (2007). Strategic management: Competitiveness and globalization. Mason, USA: South-Western.

Horn, J.T., Lovallo, D. and Viguerie, P. (2005). Beating the odds in market entry. McKinsey Quarterly, 4, 35-45.

Horst, T. (1972). Firm and industry determinants of the decision to invest abroad: An empirical study. Review of Economics and Statistics, 54 (3), 258266.

Jennings, D.F. and Young, D.M. (1990). An Empirical Comparison between Objective and Subjective Measures of the Product Innovation Domain of Corporate Entrepreneurship. Entrepreneurship Theory \& Practice, 15 (1), 53-66. 
Johanson, J. and Vahlne, J.E. (1990). The mechanisms of Internationalisation. International Marketing Review, 7 (4), 11-24.

Jones, M.V. and Coviello, N.E. (2005). Internationalization: Conceptualizing an Entrepreneurial Process of Behaviour in Time. Journal of International Business Studies, 36 (3), 284-303.

Keller, W. (2000). Do trade patterns and technology flows affect productivity growth? World Bank Economic Review, 14 (1), 17-47.

Kim, H., Hoskisson, R.E. and Lee, S.H. (2015). Why strategic factor markets matter: "New" multinationals' geographic diversification and firm profitability. Strategic Management Journal, 36, 518-536.

Kirca, A.H. et al. (2012). A multilevel examination of the drivers of firm multinationality: A meta-analysis. Journal of Management, 38 (2), 502-530.

Knight, G.A. (2000). Entrepreneurship and Marketing Strategy: The SME under Globalization. Journal of International Marketing, 8 (2), 12-32.

Laanti, R., Gabrielsson, M. and Gabrielsson, P. (2007). The globalization strategies of business-to-business born global firms in the wireless technology industry. Industrial Marketing Management, 36 (8), 1104-1117.

Lessard, D.R. (2003). Frameworks for Global Strategic Analysis. Journal of Strategic Management Education, 1 (1), 81-92.

Li, J. and Li, Y. (2010). Flexibility versus commitment: MNEs' ownership strategy in China. Journal of International Business Studies, 41 (9), 1550-1571.

Loree, D. and Guisinger, S.E. (1995). Policy and non-policy determinants of US equity foreign direct investment. Journal of International Business Studies, 26 (2), 281-299.

Lu, J.W. and Beamish, P.W. (2001). The internationalization and performance of SMEs. Strategic Management Journal, 22 (6-7), 565-586.

Madhok, A. (1997). Cost, Value, and Foreign Market Entry Mode: The Transaction and the Firm. Strategic Management Journal, 18, 39-61.

Mendoza, X. and Vives, L. (2008). De la internacionalización a la multinacionalización de la empresa: marcos teóricos para su análisis estratégico. La expansión de la multinacional española: estrategias y cambios organizativos. Barcelona, España: ESADE, ICEX.

Mendoza, X. and Vives, L. (2010). Las empresas españolas internacionalizadas: una aproximación cuantitativa. En Puig, P. (ed.), La multinacional española ante un nuevo escenario internacional (pp. 87-121). Barcelona, España: ESADE, ICEX.

Miles, M.P. and Arnold, D.R. (1991). The Relationship between Marketing Orientation and Entrepreneurial Orientation. Entrepreneurship Theory \& Practice, 15 (4), 49-65.

Miller, D. and Friesen, P.H. (1983). Strategy Making and Environment: The Third Link. Strategic Management Journal, 4, 221-235.

Miller, D. and Friesen, P.H. (1984). A Longitudinal Study of the Corporate Life Cycle. Management Science, 30 (10), 1161-1183.

McDougall, P.P. and Oviatt, B.M. (2000). International entrepreneurship: The intersection of two research paths. Academy of Management Journal, 43 (5), 902-906.

Morris, M., Avila, R. and Allen, J. (1993). Individualism and the Moderns Corporation, Implications for Innovation and Entrepreneurship. Journal of Management, 19 (3), 595-612.

Nachum, L. and Zaheer, S. (2005). The persistence of distance? The impact of technology on MNE motivations for foreign investment. Strategic Management Journal, 26 (8), 747-767.

Oviatt, B.M. and McDougall, P.P. (1994). Toward a Theory of International New Venture. Journal of International Management Business Studies, 25 (1), 45-64.

Peng, M.W. (2001). The Resource-Based View and International Business. Journal of Management, 27 (6), 803-829.

Pla-Barber, J., Sánchez, E. and Madhok, A. (2010). Investment and Control Decisions in Foreign Markets: Evidence from Service Industries. British Journal of Management, 21, 736-753.

Prahalad, C.K. and Lieberthal, K. (1998). The end of corporate imperialism. Harvard Business Review, 76 (4), 68-79. 
Prokesch, S.E. (1997). Unleashing the power of learning: An interview with British Petroleum's John Browne. Harvard Business Review, 75 (5), 146-168.

Räisänen, J.A. (2003). Evolution of Internationalization Theories Related to the Born Global Concept. Helsinki, Finland: Helsinki University of Technology.

Rashid, A., Aziz, A. and Wong, S.S. (2010). Exploring the internationalization of Malaysian contractors: The international entrepreneurship dimension. Construction Management and Economics, 28 (1), 51-61.

Reid, S. and Rosson, P. (1987). Managing Export Entry and Expansion: An Overview. En Reid, S. and Rosson, P. (Ed.), Managing Export Entry and Expansion. New York, USA: Praeger.

Reuer, J. and Ragozzino, R. (2011). The Choice Between Joint Ventures and Acquisitions: Insights from Signaling Theory. Organization Science, 23 (4), 1-16.

Root, F.R. (1983). Foreign Maiket Entry Strategies. New York, USA: AMACON.

Root, F.R. (1994). Entry Strategies for Intemational Markets. San Francisco, USA: Jossey-Bass.

Sanchez-Peinado, E., Pla-Barber, J. and Hébert, L. (2007). Strategic Variables that Influence Entry Mode Choice in Service Firms. Journal of International Marketing, 15 (1), 67-91.

Sapienza, H.J. et al. (2006). A capabilities perspective on the effects of early internationalization on firm survival and growth. Academy of Management Review, 31 (4), 914-933.

Shane, S. and Venkataraman, S. (2000). The Promise of Entrepreneurship as a Field of Research. Academy of Management Review, 25 (1), 217-226.
Sharma, M.V. and Erramilli, M.K. (2004). Resource-Based Explanation of Entry Mode Choice. Journal of Marketing Theory and Practice, 12 (1), 1-18.

Schumpeter, J.A. (1944). Teoría del desarrollo económico: una investigación sobre ganancias, capital, crédito, interés y ciclo económico. Ciudad de México, México: Fondo de Cultura Económica.

Simmonds, K. and Smith, H. (1968). The First Export Order: A Marketing Innovation. British Journal of Marketing, 2 (2), 93-100.

Terpstra, V. and Yu, C. (1988). Determinants of foreign investments of US advertising agencies. Journal of International Business Studies, 19 (1), 33-46.

Welch, L. and Luostarinen, R. (1988). Internationalization-Evolution of a Concept. Journal of General Management, 14 (2), 34-55.

Welch, L. and Luostarinen, R. (1993). Inward-outward connections in internationalization. Journal of International Marketing, 1 (1), 44-56.

Westhead, P., Wright, M. and Ucbasaran, D. (2001). The internationalization of new and small firms: A resource based view. Journal of Business Venturing, 16 (4), 333-358.

Williamson, O.E. (1985). The economic institutions of capitalism. New York, USA: The Free Press.

Zahra, S.A. and Garvis, S.M. (2000). International corporate entrepreneurship and firm performance: The moderating effect of international environment hostility. Journal of Business Venturing, 15 (5-6), 469-492. 